Original Russian Text (C) 2019 E.S. Podolskaia, K.A. Kovganko, D.V. Ershov, P.P. Shulyak, A.I. Suchkov, published in Forest Science Issues Vol. 2, No. 1, pp. 1-24

DOI 10.31509/2658-607x-2019-2-2-1-22

\title{
USING OF TRANSPORT NETWORK MODEL TO ESTIMATE TRAVELLING TIME AND DISTANCE FOR GROUND ACCESS A FOREST FIRE
}

\author{
E.S. Podolskaia ${ }^{1}$, K.A. Kovganko ${ }^{1}$, D.V. Ershov ${ }^{1}$, P.P. Shulyak ${ }^{1}$ \\ A.I. Suchkov ${ }^{2}$ \\ ${ }^{1}$ Center for Forest Ecology and Productivity of the RAS \\ Profsoyuznaya st. 84/32 bldg. 14, Moscow, 117997, Russia \\ ${ }^{2}$ Irkutsk Regional Dispatching Service \\ Deputatskaya st. bldg. 85, Irkutsk, 664081, Russia \\ E-mail:podols_kate@mail.ru \\ Received 11 January 2019
}

Since regional forest protection services often have limited material resources, the emergency response to the emerging forest fires requires to choice an optimal maneuvering solution and a method to transfer available forces. One of the possible ways is to create a regional transport model for the case of forest fire based on the network of public roads and forest glades. Paper describes a method of calculation of travelling time and distance to a forest fire, research results for an experimental transport model, created by Network Analyst ArcGIS, to build the shortest routes from the fire stations to the forest fires. Spatially-distributed data on the fire trucks' average speed for different types of roads and the elevation values were used in the model for the test area (Irkutsk region of Russia). In total 16251 routes were built and analyzed for 16 years (2002-2017). The model was validated using the data on forest fires detected by the MODIS-Aqua/Terra spectroradiometer within the ground and forest aviation zones of test region. A map showing the fire routes within one-, two- and three- hours ground transport accessibility is created for the forest fire ground protection zone of the test region. The model's work quality was validated for the forest fires detected within the ground zone. As a result, 98\% (2661) of forest fires in the ground zone are accessible within three hours and less, that indirectly confirms the correctness of model. At the same time, the majority of forest fires are located within one- (68\%) and two- (24\%) hour's availability. Finally, recommendations on using the transport model for the managerial decisions on the forest fire fighting on regional level were given.

Key words: transport model, ArcGIS, Network Analyst, forest fire, fire protection zones, fire station 
Active studies to organize an access to the emergency zones, delivery of different goods, urban planning, forest management and transport logistics and other applied areas are being conducted by domestic and foreign research groups (Liu, Zhu, 2004; Kumar et al., 2005; Sokolov, Gerasimov, 2009; Akay et al., 2012; Forkuo et al., 2013; Ni et al., 2014; Akay, Aziz, 2015; Idhoko et al., 2015; Abousaeidi et al., 2016a; Abousaeidi et al., 2016b; Malladi, Sowlati, 2017; Feng et al., 2017; Keramati, 2018).

Forest fires, annually occurring in different regions of Russia, cause significant damage to the country's economy. Besides to their timely detection, there is a task of promptly delivery of fire brigade and special equipment to the forest fire. Under the conditions of high and extreme forest fieriness, choice of a method (ground or aviation) to deliver the forces and equipment from a fire-and-chemical (PHS - Russian acronym for Fire Station) station to the forest fire is an actual problem in the forest fire control at the regional level.

Methods of mathematical modeling are used to solve the task to design a forest transportation network and access optimization for the forest areas (Khodakov, Zharikova, 2011; Runova, Kostyaev, 2012; Tarantsev, 2013; Faraonov, 2014). Modeling is conducted by the well-known office programs, as well as with the help of geo-information systems tools. We note that the important issue of defining the protection zones boundaries was discussed in scientific publications in a debatable way (Tarantsev, 2015), where Microsoft Excel tools were used for the analysis.

Integration of transport spatial models and remote sensing data (Earth remote sensing) on forest fires in modern geographic information systems can be a new level of development in this area. GIS technologies allow designing traffic routes in space, evaluating a set of parameters for decision making when organizing forest firefighting (Loupian et al., 2006) and logistics (Abousaeidi et al., 2016b; Feng et al., 2017).

As it was noted in the paper (Kotelnikov et al., 2017), insufficient funding of forest fires detection and organization of the forest firefighting in Russia practically means the necessity of resources dispatching. This article also underlines the need for retrospective data collection and updating the knowledge base on the access to forest fires. Present study is a development of this direction and is carried out by both creating a multi-year archive of access routes and its thematic analysis.

The problem to organize the operational transfer of forces and means to the forest fire sites is still actual for many "forest" countries, taking into account the national specifics of forest management, forest growing conditions, local climate, terrain and road network features. 
We can mention among foreign works the following articles (Kumar et al., 2005; Akay et al., 2012; Akay, Aziz, 2015) on the similar topic.

In accordance with Russian Forest Code, administrative units of Russia are engaged in the detection and suppression of forest fires. Some certain regulations, rules and terminology that have been formulated on the federal and regional levels over the past decade to describe the organization of access to the forest fire sites, for example, (On approval of the classification of natural forest fire danger, 2011).

There is one valid document (Recommendations on the use of forces and technical means, 2014), among the other existing regulatory documents, which states that access to the detected forest fire should be organized within three hours from the moment of its detection. Namely, paragraph 48 of the guidelines recommends that in order to ensure the prompt elimination of forest fire a forest firefighting division should arrive at the forest fire place and start its extinguishing work:

(a) if Forests classified as Class I of the natural fire danger - no later than one hour after the forest fire detection;

(b) if Forests classified as Class II of the natural fire danger - no later than two hours after the fire detection;

(c) if Forests assigned to the III - V classes of the natural fire danger - not later than three hours after the fire detection.

Important aspects of collaboration between the ground and aviation forces were investigated in the following papers (Bryukhanov, 2011; Bryukhanov et al., 2017), among the topics covered there are an urgent need for state funding, and the importance of interaction between the aviation crews and ground forces is highlighted when organizing work by aviation or ground methods.

The purpose of present study is to make an estimation of travelling time and distance from the nearest fire station to a detected forest fire while driving a special vehicle (fire truck, tank truck, patrol car, etc.) along the public and special roads, including fire roads and forest glades, within the ground protection zone by the example of the Irkutsk region.

To do so the following tasks have been formulated:

- Creation of ground forest fire transport model for the test region;

- Creation of access routes from fire stations to the forest fires, 
- Calculation of travelling time and travelled distance of firefighting trucks for the archiving data of 16 years (2002-2017);

- Statistical estimation of forest fires number within the ground and aviation protection zones where the trucks can be delivered in less than three hours;

- Creation of map of forest fire sites distribution within one-two-three hour's accessibility in ground and aviation zones (data of protection zones boundaries are of 2017).

\section{MATERIALS AND METHODS}

Study included the stages to create the region's transport network using ArcGIS tools and extensions, then to build a forest fire transport model for ground access using the data on public roads, forest glades, fire stations, and forest fire sites. At the final stage, shortest routes to forest fires are being created based on proposed model, then the calculation of travelling time, taking into account the elevation values and putting the routes into a database.

Thus, we have implemented the following sequence "Fire station (point) - Access route (polyline) - Forest fire (point)". A scheme which includes all steps of data processing and analysis is shown on the Fig. 1.

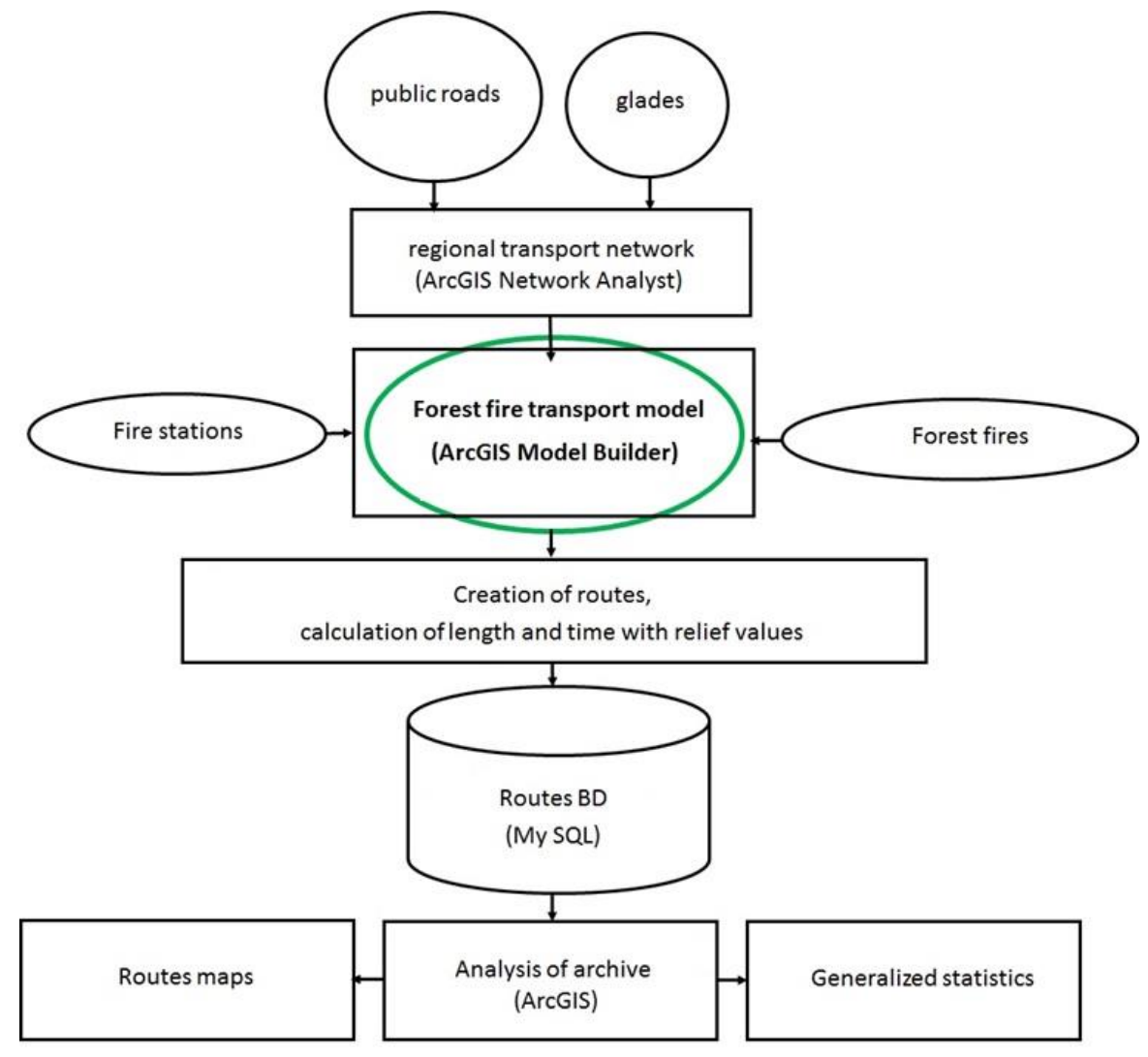

Fig. 1. Study design 
Irkutsk region has been chosen as test area because of its high annual forest inflammability during the fire hazard season (Goldammer et al., 2003; Runova, Dolenko, 2006; Ponomarev et al., 2017). As it was shown in the paper (Kaibicheva, Kaibichev, 2013), Irkutsk region is ranked 6-2-3-8-9 on the Dow Jones forest fire index (number of forest fires) within the time interval of 5 consecutive years (2006-2010), in which 30 Russian regions were included in the selection. These statistics indicate the relevance of choosing such region as a typical example.

For the test region we used geodatabase with settlements of point and polygon types, road network (including forest glades), hydrographic objects and administrative division of 1:200 000. Datasets of such scale are characterized by necessary details and spatial extent to perform a regional level study, which allows to organize access in the emergency situations (Oleynikov, Markov, 2014). Data on forest fire stations are represented by points (their actual geometry and attributes are as of 2017), data on the detected forest fires are received from spectroradiometr MODIS from Aqua and Terra satellites.

Map with average number (according to the satellite data of 2006-2012) of forest fires in relation to the Fire stations of different levels is shown on the Fig. 2. We can see from the map that forest fires frequency visually correlates to the location of fire station in the region. Symbols of fire stations are given in accordance with the normative document (Legend for the forest fire prevention, 1997).

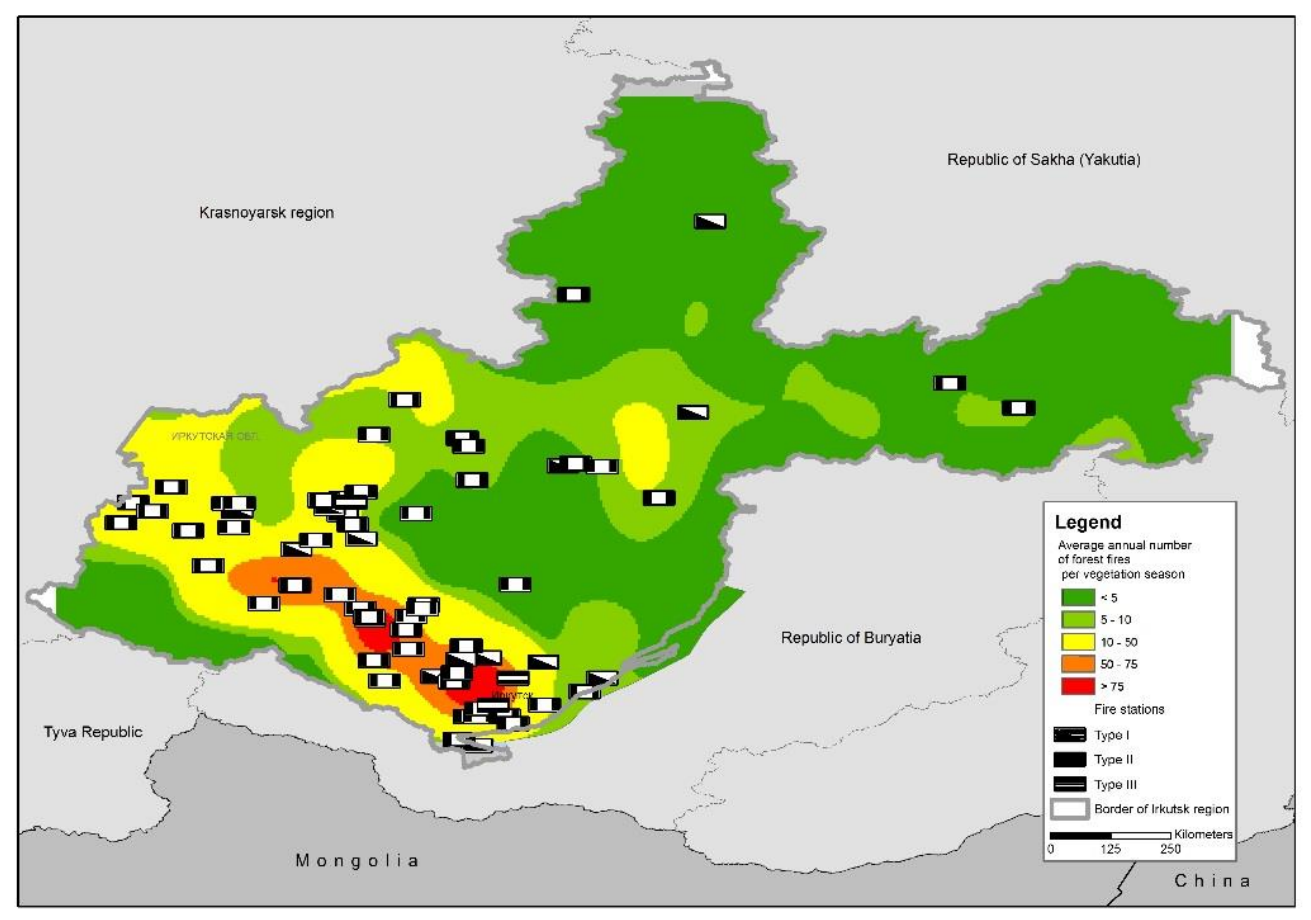

Fig. 2. Average annual number of forest fires per growing season in the Irkutsk region 
In 2017 the territory of Irkutsk region's forest fund was divided into four forest protection zones (Order of Rosleskhoz No 65, 2017), namely:

- Ground detection and extinguishing zone;

- Zone of forest aviation works, including:

- zone of aviation detection and ground extinguishing;

- zone of aviation detection and extinguishing;

- zone of satellite exclusive detection and mainly aviation works.

On June 21, 2017, the order of the Ministry of Forestry of the Irkutsk Region (Order Ministry No 52) has defined a control zone in the forest fund for remote and hard-to-reach territories with the lack of road infrastructure and the underdeveloped road network (Fig. 3). It included the zone of satellite detection and a part of the aviation detection zone. Forest fire fighting is carried out within the borders of ground and forest aviation zones. In the control zone the necessity of extinguishing works is based on the decision of the Commission for the Prevention and Elimination of Emergencies and Ensuring Fire Safety, Government of the Irkutsk Region. Thus, calculations and analysis of created shortest access routes were carried out for ground protection and forest aviation zones. Forest aviation zone covers approximately $48 \%$ of Irkutsk region's territory.

We have used ArcGIS extensions for the calculations: 3D Analyst and Network Analyst. Network Analyst based on the Dijkstra's algorithm (Dijkstra, 1959), was used to create a transport model. This algorithm is shown on graphs and allows finding the shortest paths from one of the graph nodes to all the others. The algorithm is widely used in the transport studies (How to create..., 1996; Ni et al., 2014), there are some modifications, for example, (Alazab et al., 2011).

According to the Dijkstra's algorithm we named created access routes the shortest ones. A set of Network Analyst modules was used. Using the Model Builder visual programming environment we have created a model with the help of the following tools: Add Locations, Solve (decision making), and Make Closest Facility Layer (creating the shortest distance layer). 3D Analyst was used to calculate the road slope (Add Z Information tool), in addition, Adjust 3D Z (assignment of elevation characteristic to the polyline) from the Data Management set was used.

Calculation of roads length and travelling time from a fire station to the detected forest fire was performed using the Add Field (adding a new field in the attribute table) and Calculate 
Field (obtaining the numerical characteristics of the polyline). Statistical estimation of the number of forest fires within the ground and aviation zones was carried out using the methods of mathematical statistics.

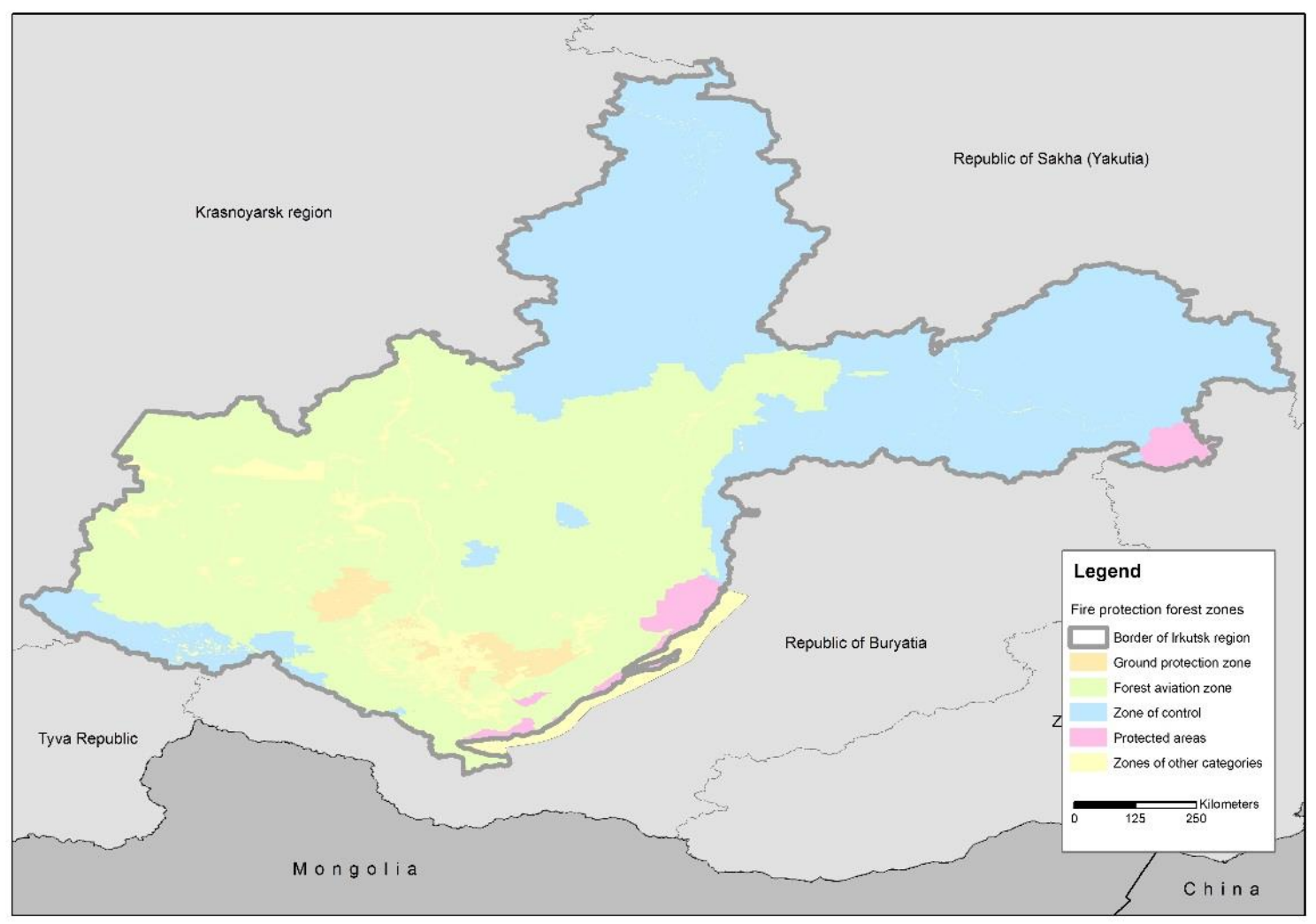

Fig. 3. Fire protection forest zones in the Irkutsk region

Table 1 lists the types of roads throughout the Irkutsk Region (a geodatabase of 1: 200 000 was used), indicating the length and speed of special vehicles (fire trucks). Due to the statistical (Federal State Statistics Service) fact of insignificant Irkutsk region's road network's changes over the past four years (2014-2018) and their average value of 3.5\% per year (Territorial department of Federal State Statistics Service for Irkutsk region), these data can be used to create a regional transport model and to do the further research. Field forest roads and trails add up to about half of the total length of all the roads, and there is quite important percentage of forest glades $(22 \%)$. 
Table 1. Roads distribution by type of use

\begin{tabular}{|l|c|c|c|}
\hline $\begin{array}{c}\text { Road type according to the classification of } \\
1: 200 \text { 000 topographic map }\end{array}$ & $\begin{array}{c}\text { Russian } \\
\text { normatives of } \\
\text { speed, km/h }\end{array}$ & $\begin{array}{c}\text { 3D length, km (taking } \\
\text { into account relief } \\
\text { values) }\end{array}$ & $\begin{array}{c}\text { Percentage from } \\
\text { total length in the } \\
\text { region, \% }\end{array}$ \\
\hline highways & 60 & 13128.2 & 7.0 \\
\hline improved roads & 60 & 1471.6 & 0.8 \\
\hline highways & 50 & 2988.4 & 1.6 \\
\hline unpaved dirt roads & 40 & 12663.1 & 6.8 \\
\hline dirt roads & 30 & 9978.9 & 5.4 \\
\hline unpaved and forest roads & 20 & 48095.5 & $\mathbf{2 5 . 8}$ \\
\hline improved roads under construction & 20 & 37.7 & 0.02 \\
\hline highways under construction & 20 & 137.9 & 0.07 \\
\hline unpaved dirt roads under construction & 20 & 376.8 & 0.2 \\
\hline paths and trails & 5 & 46924.9 & $\mathbf{2 5 . 2}$ \\
\hline hiking trails and paths & 5 & 858.8 & 0.4 \\
\hline winter roads & 10 & 5610.3 & 3.0 \\
\hline streets in the settlements & 25 & 2338.9 & 1.2 \\
\hline technical lines & 10 & 908.5 & 0.51 \\
\hline glades & 10 & 40964.7 & $\mathbf{2 2}$ \\
\hline & Total length, $\mathrm{km}$ & 186484.6 & \\
\hline
\end{tabular}

As we can see from the Fig. 4, combination of roads with the forest glades layer can expand the forest trucks' access to the forest.

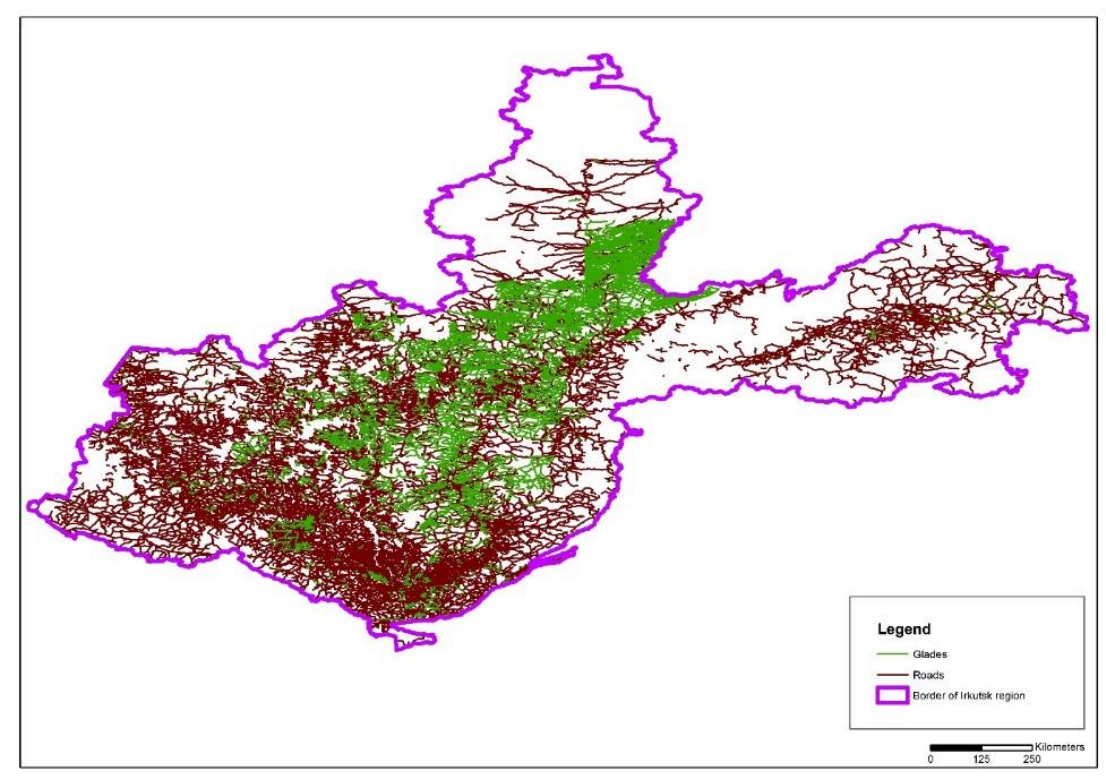

Fig. 4. Data on roads and glades in the Irkutsk region 
The combination of data on the two types (roads and glades) allows to simulate the options for moving on all the roads and to differentiate the movement of special transport, depending on the classes and conditions (seasonality) of their use.

\section{THEORY AND CALCULATIONS}

Following input parameters were used to create a transport model:

1. Time. This parameter is used to estimate the time spent on moving a vehicle with fire extinguishing forces to the detected forest fire, taking into account the time constraints for different classes of natural forest fire hazard. Among the examples, we note the article on minimizing access time when planning relocation in the city (Jawad et al., 2016).

2. Normatives of speed depending on the road's type. Movement on different road types is carried out at different speed, according to the Russian Traffic Regulations. For the fire trucks we use a speed limit of $60 \mathrm{~km}$ per hour (a truck with passengers), speed within the settlements is $25 \mathrm{~km}$ per hour. As noted in (Akay, Kakol, 2014), the speed of firefighting vehicle's movement is determined by the road type and road conditions (such as weather, visibility, etc.). In the present study the road hierarchy is presented in the Table 1, where we give the ranking of road types and special vehicles speed based on the Russian norms.

3. Elevation. Irkutsk region is characterized by significant differences in altitudes which can greatly affect the speed of special trucks. To take this circumstance into account, every segment of the road and glade must be assigned an elevation value. For the present research we have used an open-access model NOAA ETopo.

Taking into consideration data on the altitude allows to correct (decrease) the vehicle's speed in the mountainous conditions. Each road (or glade) is a polyline consisting of elementary straight lines (or segments) between two adjacent points. Polylines were converted into points, a height value from the elevation raster was added to each of the points.

To adjust the speed on every segment of road/glade we have used the slope coefficient R:

$$
R=\frac{\text { Erv-Srv }}{\mathrm{L}},(1)
$$

where: Erv, Srv - elevation values from ETopo2 for the first (beginning) and last (ending) points of polyline, $\mathrm{m} ; \mathrm{L}$ - length of polyline, $\mathrm{m}$. 
Then R-coefficient was added to the attributes of polylines, so we can calculate the speed among the full length of road/glade:

$$
\mathrm{Vc}=\mathrm{V}-|V * R|,
$$

where: $\mathrm{Vc}$ - speed with 3D value included, $\mathrm{km}$ per hour, $\mathrm{V}$ - normative speed of special vehicle, $\mathrm{km}$ per hour.

Calculation of R-coefficient for the roads and glades showed that $30 \%$ of their length within the studied data set in the Irkutsk region has a slope factor close to "1". The rest of the road network requires a speed adjustment depending on the terrain slope, so this confirms the need of 3D-adjustment procedure. The speed is adjusted downwards depending on the relief drop (ascent or descent) on the route.

At the final stage of transport model construction we calculate travelled time taking into account 'adjusted" speed with the formula:

$$
\mathrm{Tm}=\frac{\mathrm{L} 3 d}{\mathrm{Vc}} * 60
$$

where: Tm - movement time время with 3D value, minutes; L3d - length with 3D value, $\mathrm{km}$.

Thus, the transport model contains all the necessary information about roads, speed and travel time on each segment of the road/glade, taking into account the terrain slope. Calculations were done in ArcGIS Desktop.

In Fig. 5 shows the model of the road network within the boundaries of ground protection and forest aviation zones with the speed distribution with the slope coefficient (3D value).

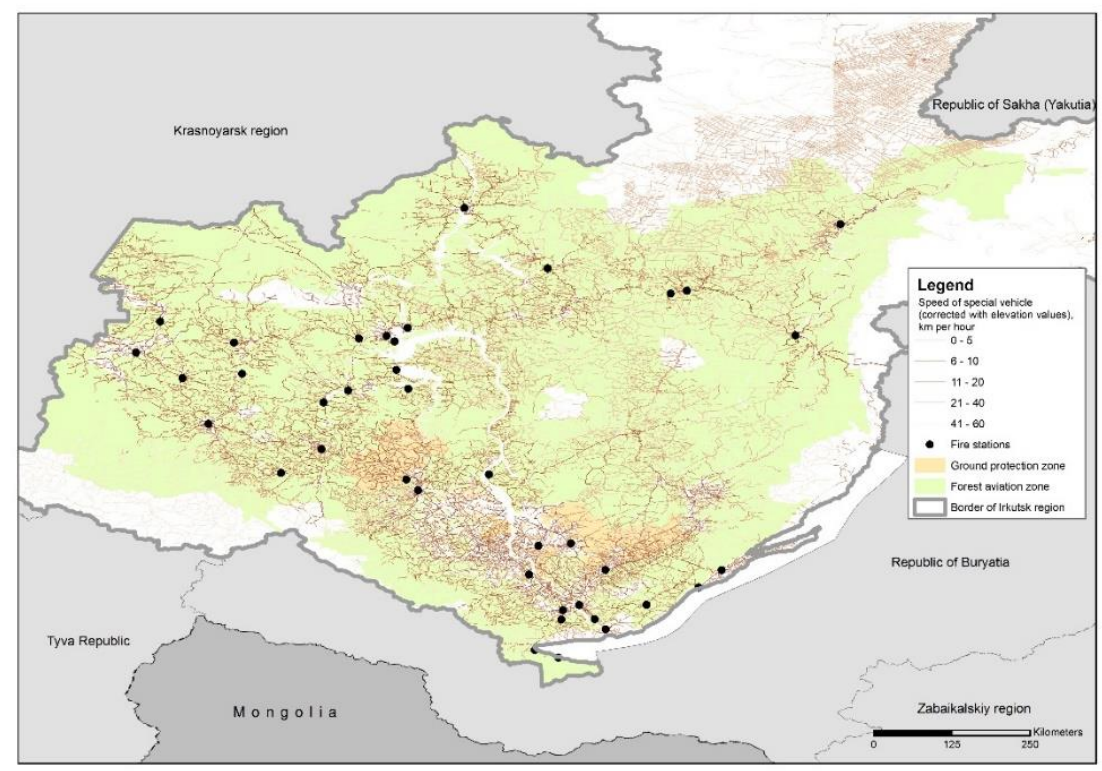

Fig. 5. Forest fire transport model of ground access by special transport in the Irkutsk region 
Based on the collection of routes to fires in the database, a statistical analysis of the fires number within one, two, three and more than three-hour intervals is performed (Recommendations on the use of forces and technical means, 2014). According to these recommendations, one of the requirements when designing a ground protection zone is the arrival time limitation, namely, not more than three hours from the forest fire's detection moment. Thus, assuming that the ground zone is designed correctly, the correctness of setting the transport model's parameters is indirectly verified. If the majority of fires registered in the ground protection zone would have the access time of less than three hours, then we could assume that the model works close to the real situation.

\section{DISCUSSION}

As an implementation of the methodology, described above, the shortest access routes were created for the archive of forest fires, detected in 2002-2017 within the ground and aviation protection zones. Access routes were created under condition that fire stations and detected forest fires were located within these two zones. Every fire hazard season has its assessment of route's travelled length and transportation time. Fig. 6 shows distribution of 16251 access routes.

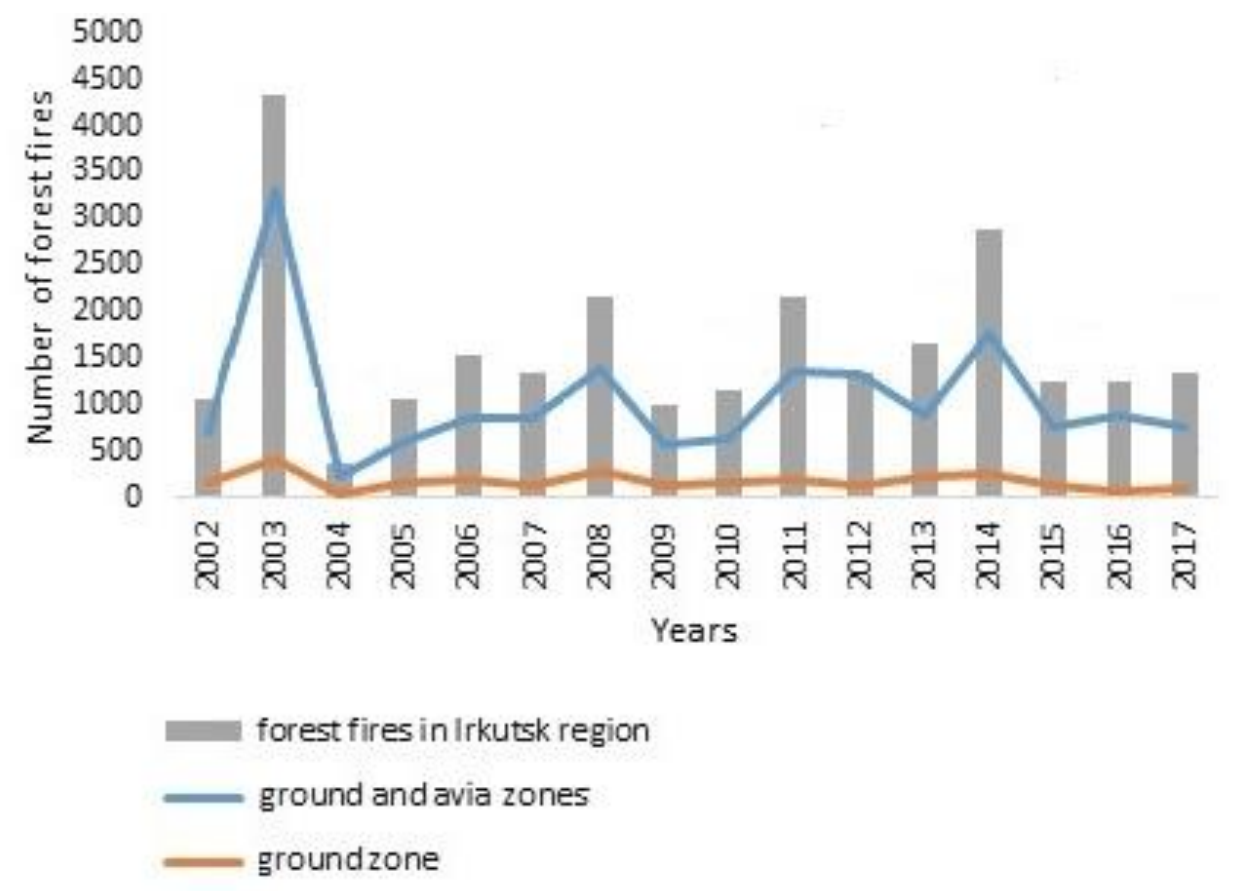

Fig. 6. Forest fires number detected in the Irkutsk region and the access routes created within the ground and forest aviation protection zones 
As can be seen from the Fig. 6, the minimum number of routes (236) was built for the data of 2004, the maximum (3297) - is for 2003, which indicates important differences in the number of detected forest fires from different years and their accessibility by ground means. We note that the number of days during which forest fires occurred during the fire hazard season varies from 170 to 213 days, so the range is more than one month (43 days). The analysis of travelled time and length is given in the Table. 2

Table 2. Statistics of created forest fire routes (analysis of time and length)

\begin{tabular}{|c|c|c|c|c|c|c|c|c|}
\hline $\begin{array}{l}\text { Year of } \\
\text { fire } \\
\text { hazard } \\
\text { season }\end{array}$ & $\begin{array}{c}\text { Beginning of } \\
\text { fire season } \\
\text { within two } \\
\text { zones } \\
\text { (date/month) }\end{array}$ & $\begin{array}{c}\text { Ending of } \\
\text { fire season } \\
\text { within two } \\
\text { zones } \\
\text { (date/month) }\end{array}$ & $\begin{array}{l}\text { Number } \\
\text { of days } \\
\text { with } \\
\text { forest } \\
\text { fires }\end{array}$ & $\begin{array}{c}\text { Min } \\
\text { length, } \\
\text { km }\end{array}$ & $\begin{array}{l}\text { Min time, } \\
\text { minutes }\end{array}$ & $\begin{array}{l}\text { Max length, } \\
\text { km }\end{array}$ & $\begin{array}{l}\text { Max time, } \\
\text { minutes }\end{array}$ & $\begin{array}{l}\text { Max time, } \\
\text { hours }\end{array}$ \\
\hline 2002 & $11 / 04$ & $5 / 10$ & 177 & 0.91 & 0.004 & 431.34 & 2032.14 & 33.87 \\
\hline 2003 & $4 / 04$ & $24 / 10$ & 203 & 1.23 & 2.74 & 634.09 & 3164.78 & 52.75 \\
\hline 2004 & $22 / 04$ & $31 / 10$ & 192 & 1.33 & 3.21 & 419.97 & 1870.11 & 31.17 \\
\hline 2005 & $01 / 04$ & $28 / 10$ & 210 & 0.80 & 1.50 & 607.65 & 3025.91 & 50.43 \\
\hline 2006 & $23 / 04$ & $10 / 10$ & 170 & 2.16 & 2.69 & 616.21 & 3086.06 & 51.43 \\
\hline 2007 & $09 / 04$ & $27 / 10$ & 184 & 2.41 & 4.29 & 378.18 & 1503.75 & 25.06 \\
\hline 2008 & $01 / 04$ & $30 / 10$ & 212 & 0.20 & 0.001 & 498.00 & 2411.86 & 40.20 \\
\hline 2009 & $01 / 04$ & $31 / 10$ & 212 & 1.88 & 3.37 & 440.10 & 2047.24 & 34.13 \\
\hline 2010 & 08/04 & $31 / 10$ & 206 & 2.82 & 4.36 & 626.24 & 3133.80 & 52.23 \\
\hline 2011 & $01 / 04$ & $24 / 10$ & 206 & 1.60 & 2.74 & 629.05 & 3155.45 & 52.59 \\
\hline 2012 & $01 / 04$ & $28 / 10$ & 210 & 0.20 & 0.48 & 632.67 & 3181.04 & 53.02 \\
\hline 2013 & $13 / 04$ & $31 / 10$ & 201 & 0.28 & 0.001 & 627.76 & 3136.24 & 52.27 \\
\hline 2014 & $01 / 04$ & $31 / 10$ & 213 & 0.12 & 0.001 & 626.87 & 3136.24 & 52.27 \\
\hline 2015 & 03/04 & $29 / 10$ & 209 & 3.77 & 3.38 & 626.74 & 3130.32 & 52.17 \\
\hline 2016 & $02 / 04$ & $22 / 10$ & 203 & 0.86 & 0.01 & 609.78 & 3051,27 & 50.85 \\
\hline 2017 & $01 / 04$ & $30 / 10$ & 212 & 2.46 & 2.64 & 612.61 & 3056.30 & 50.94 \\
\hline \multicolumn{3}{|c|}{ Total } & 3220 & 23.03 & 31.42 & 9017.26 & 44122.51 & 735.38 \\
\hline \multicolumn{3}{|c|}{ Average value } & 201 & 1.43 & 1.96 & 563.58 & 2757.66 & 45.96 \\
\hline \multicolumn{3}{|c|}{ Standard deviation } & 24.7 & 1.10 & 1.86 & 128.18 & 724.19 & 12.07 \\
\hline
\end{tabular}

Distribution number of routes registered within the ground protection zone based on the time limit of three-hour interval (absolute values and percentage) is presented in the Table 3.

As can be seen from the Table. 3, most of the fires (2661 or 98.5\%) registered within the ground protection zone are accessible in three hours. This indirectly confirms the 
correctness of transport model's settings and shows that the ground protection zone was designed with taking into account the possible arrival to the forest fire within three hours. At the same time, the majority of forest fires are located at hourly (1754 or 68.2\%) and two-hour (744 or $24.3 \%$ ) availability from the fire stations.

Table 3. Routes distribution depending on the travelled time for the fires detected within the ground protection zone

\begin{tabular}{|c|c|c|c|c|c|c|c|c|c|c|c|}
\hline \multirow[t]{2}{*}{$\begin{array}{c}\text { Year of fire- } \\
\text { dangerous season }\end{array}$} & \multirow{2}{*}{\begin{tabular}{|c|} 
Number of \\
routes created \\
within ground \\
protection \\
zone
\end{tabular}} & \multicolumn{5}{|c|}{$\begin{array}{c}\text { Number of routes classified by travelling } \\
\text { time }\end{array}$} & \multicolumn{5}{|c|}{ Percentage of total number of routes, $\%$} \\
\hline & & $\begin{array}{c}\text { less } \\
\text { than 1 } \\
\text { hour }\end{array}$ & $\begin{array}{c}1-2 \\
\text { hours }\end{array}$ & $\begin{array}{c}2-3 \\
\text { hours }\end{array}$ & $\begin{array}{c}\text { totally } \\
\text { within } 3 \\
\text { hours }\end{array}$ & $\begin{array}{l}\text { more } \\
\text { than } 3 \\
\text { hours }\end{array}$ & $\begin{array}{c}\text { less than } \\
1 \text { hour }\end{array}$ & $\begin{array}{c}1-2 \\
\text { hours }\end{array}$ & $\begin{array}{c}2-3 \\
\text { hours }\end{array}$ & $\begin{array}{c}\text { totally } \\
\text { within } 3 \\
\text { hours }\end{array}$ & $\begin{array}{l}\text { more } \\
\text { than } 3 \\
\text { hours }\end{array}$ \\
\hline 2002 & 155 & . & 46 & 21 & 155 & 0 & 56.8 & 29.7 & 13.5 & 100 & 0 \\
\hline 2003 & 419 & 202 & 164 & 37 & 403 & 16 & 48.2 & 39.1 & 8.8 & 96.2 & 3.8 \\
\hline 2004 & 30 & 26 & 4 & 0 & 30 & 0 & 86.7 & 13.3 & 0 & 100 & 0 \\
\hline 2005 & 170 & 111 & 46 & 12 & 169 & 1 & 65.3 & 27.1 & 7.1 & $\begin{array}{l}99.4 \\
\end{array}$ & 0.6 \\
\hline 2006 & 190 & 125 & 56 & 9 & 190 & 0 & 65.8 & 29.5 & 4.7 & 100 & 0 \\
\hline 2007 & 124 & 103 & 20 & 1 & 124 & 0 & 83.1 & 16.1 & 0.8 & 100 & 0 \\
\hline 2008 & 297 & 192 & 97 & 7 & 296 & 1 & 64.6 & 32.7 & 2.4 & 99.7 & 0.3 \\
\hline 2009 & 117 & 74 & 27 & 14 & 115 & 2 & 63.2 & 23.1 & 12.0 & \begin{tabular}{|c|}
98.3 \\
\end{tabular} & 1.7 \\
\hline 2010 & 148 & 106 & 38 & 3 & 147 & 1 & 71.6 & 25.7 & 2.0 & 99.3 & 0.7 \\
\hline 2011 & 193 & 127 & 55 & 8 & 190 & 3 & 65.8 & 28.5 & 4.1 & 98.4 & 1.6 \\
\hline 2012 & 125 & 93 & 23 & 7 & 123 & 2 & 74.4 & 18.4 & 5.6 & 98.4 & 1.6 \\
\hline 2013 & 213 & 158 & 47 & 7 & 212 & 1 & 74.2 & 22.1 & 3.3 & 99.5 & 0.5 \\
\hline 2014 & 245 & 159 & 68 & 13 & 240 & 5 & 64.9 & 27.8 & 5.3 & 98.0 & 2.0 \\
\hline 2015 & 120 & 81 & 29 & 10 & 120 & 0 & 67.5 & 24.2 & 8.3 & 100 & 0 \\
\hline 2016 & 65 & 43 & 10 & 8 & 61 & 4 & 66.2 & 15.4 & 12.3 & 93.8 & 6.2 \\
\hline 2017 & 90 & 66 & 14 & 6 & 86 & 4 & 73.3 & 15.6 & 6.7 & 95.6 & 4.4 \\
\hline Total & 2701 & 1754 & 744 & 163 & 2661 & 40 & & & & & \\
\hline Average value & 168.8 & 109.6 & 46.5 & 10.2 & 166.3 & 2.5 & 68.2 & 24.3 & 6.1 & 98.5 & 1.5 \\
\hline $\begin{array}{l}\text { Standard } \\
\text { deviation }\end{array}$ & 45.9 & 15.6 & 22.6 & 10.6 & 48.8 & 2.8 & 11.7 & 10.0 & 4.8 & 3.1 & 3.1 \\
\hline
\end{tabular}

If we look at the ratio of all routes (16251) created from the fire stations to the forest fires in relation to the ground protection and forest aviation zones, then most of the fires (Fig.7) are accessible by ground transport within three hours from the detection moment. The only exceptions are the fire hazard seasons of 2012 and 2016. On average for the 16 years, the 
number of routes with the delivery time of less than three hours is $76.2 \%( \pm 13.2 \%)$ versus $23.8 \%( \pm 13.2 \%)$. Generally, based on the created graphs, it means that most of the forest fires are timely accessible by ground transport means.

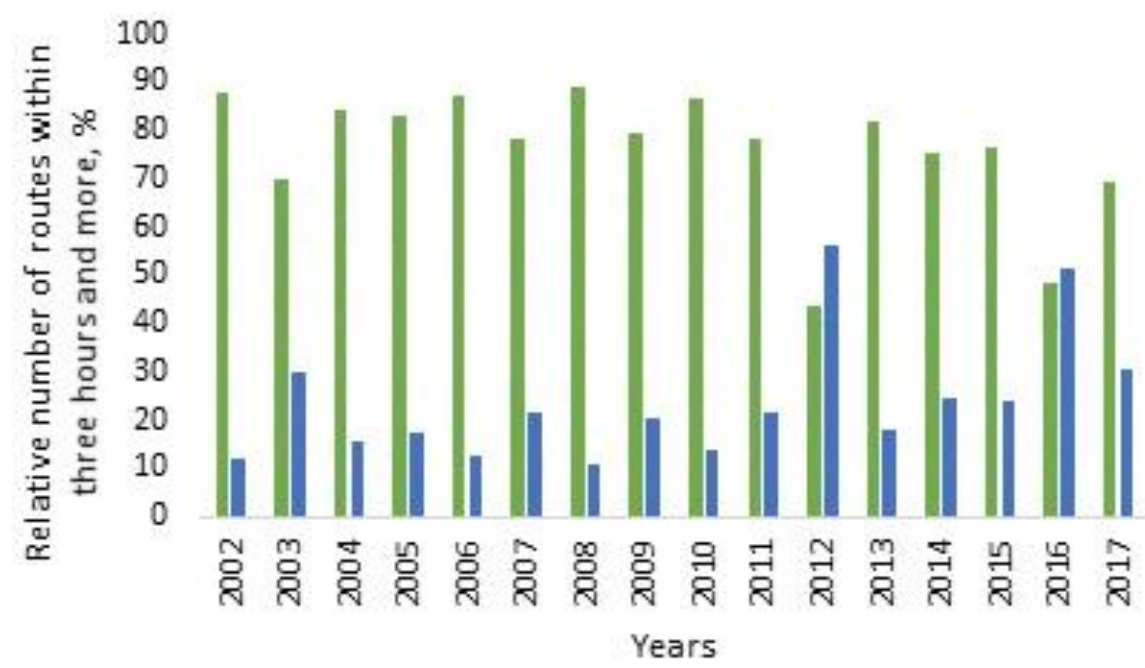

Fig. 7. Distribution of relative numbers of routes (\%) to the forest fires within the ground and aviation protection zones, travelled time is three (green color) and more (blue color) hours

Cartographic part of the analysis is represented by a map with the created access routes for the archive of forest fires of 2002-2017 (Fig. 8) within the ground protection zone with the time differentiation, namely: within one hour, one to two hours and two to three hours.

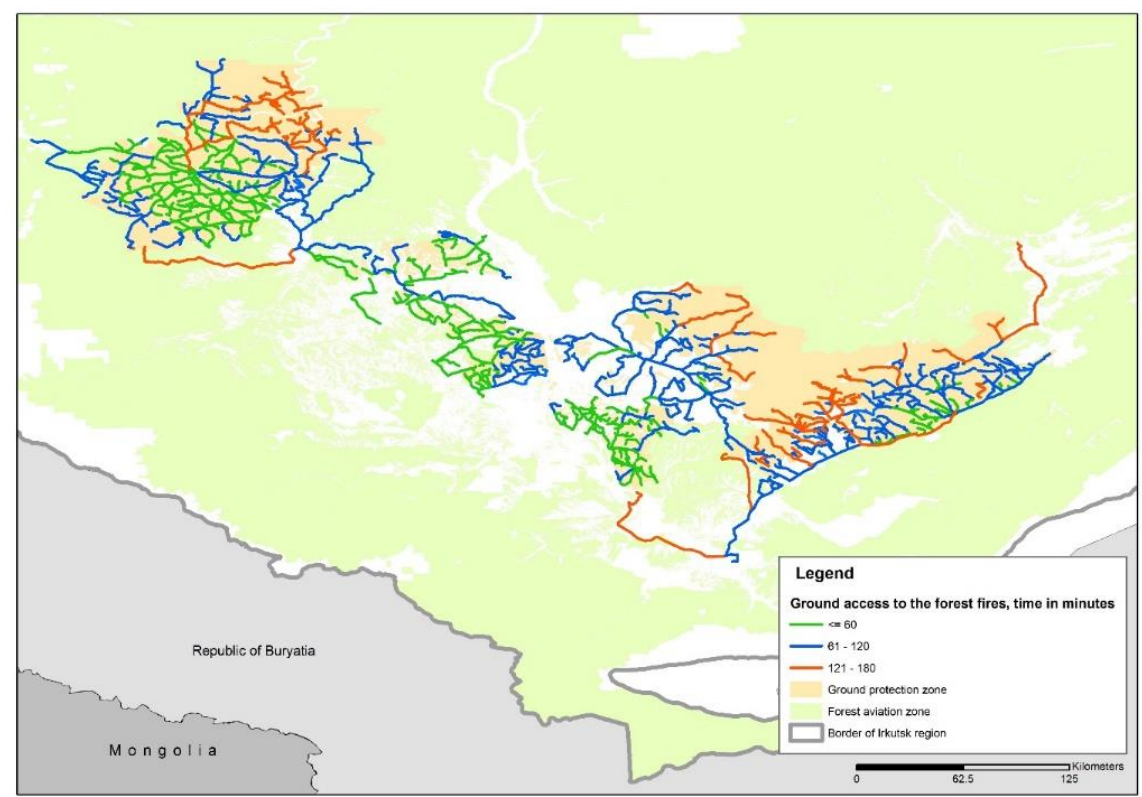

Fig. 8. Map of forest fire routes in the ground protection zone classified by travelling time

The Fig. 8 shows that some of the routes go beyond the boundaries of the ground protection zone, which confirms the need to take into account the statistics of vehicles 
movement and the routes length during the annual correction of ground protection zone's and forest aviation zone's boundaries. It's graphically shown that the ground protection zone can be extended.

This is also confirmed by the statistics of routes distribution within a three-hour interval (Table 4). Calculations took into account the forest fires location relative to the zones to verify the possibility to change the boundaries of these two monitoring zones. According to the data from this Table, the ground zone can also be extended.

Table 4. Characteristics of access routes (archive 2002-2017) within the protection zones (forest fires were detected in the zones)

\begin{tabular}{|c|c|c|c|c|c|}
\hline \multirow{2}{*}{$\begin{array}{l}\text { Year of fire- } \\
\text { dangerous } \\
\text { season }\end{array}$} & \multirow{2}{*}{$\begin{array}{l}\text { Number of } \\
\text { routes within } \\
\text { two zones }\end{array}$} & \multicolumn{2}{|c|}{$\begin{array}{l}\text { Number of forest fires within } \\
\text { protection zones }\end{array}$} & \multicolumn{2}{|c|}{$\begin{array}{l}\text { Percentage of forest fires within two zones } \\
\text { relative to the total number of routes, } \%\end{array}$} \\
\hline & & ground & aviation & ground & aviation \\
\hline 2002 & - & 155 & 553 & 21.9 & 78.1 \\
\hline 2003 & 3297 & 419 & 2878 & 12.7 & 87.3 \\
\hline 2004 & 236 & 30 & 206 & 12.7 & 87.3 \\
\hline 2005 & 588 & 170 & 418 & 28.9 & 71.1 \\
\hline 2006 & 847 & 190 & 657 & 22.4 & 77.6 \\
\hline 2007 & 859 & 124 & 735 & 14.4 & 85.6 \\
\hline 2008 & 1379 & 297 & 1082 & 21.5 & 78.5 \\
\hline 2009 & 557 & 117 & 440 & 21.0 & 79.0 \\
\hline 2010 & 618 & 148 & 470 & 23.9 & 76.1 \\
\hline 2011 & 1356 & 193 & 1163 & 14.2 & 85.8 \\
\hline 2012 & 760 & 125 & 635 & 16.4 & 83.6 \\
\hline 2013 & 869 & 213 & 656 & 24.5 & 75.5 \\
\hline 2014 & 1764 & 245 & 1519 & 13.9 & 86.1 \\
\hline 2015 & 772 & 120 & 652 & 15.5 & 84.5 \\
\hline 2016 & 878 & 65 & 813 & 7.4 & 92.6 \\
\hline 2017 & 763 & 90 & 673 & 11.8 & 88.2 \\
\hline Total & 16251 & 2701 & 13550 & & \\
\hline Average value & 1015.7 & 317.8 & 1594.1 & 17.7 & 82.6 \\
\hline $\begin{array}{l}\text { Standard } \\
\text { deviation }\end{array}$ & 709.4 & 94.4 & 628.2 & 5.8 & 5.9 \\
\hline
\end{tabular}

If we consider the full length of the routes from fire stations to fires (Table 5) within the ground protection and forest aviation zones, the model allowed to build 1 million 218 
thousand $208.1 \mathrm{~km}$ of routes from 2002 to 2017 . On average, the routes length per year is $76,138 \mathrm{~km}$, of which $36,311.1 \mathrm{~km}(47.7 \%)$ are within three-hour accessibility. At the same time, the ground zone covers the total of $96,201 \mathrm{~km}$ of roads over 16 years, which on average is $6,012.6 \mathrm{~km}$ or $7.9 \%$.

Table 5. Characteristics of routes archive 2002-2017 by travelled distance

\begin{tabular}{|c|c|c|c|c|c|c|c|}
\hline \multirow{2}{*}{$\begin{array}{l}\text { Year of fire- } \\
\text { dangerous } \\
\text { season }\end{array}$} & \multirow{2}{*}{\begin{tabular}{|c|} 
Total length per \\
season within \\
two zones, km
\end{tabular}} & \multicolumn{6}{|c|}{ Length of routes within ground and aviation protection zones } \\
\hline & & $\begin{array}{c}\text { less than } 1 \\
\text { hour }\end{array}$ & $1-2$ hours & 2-3 hours & $\begin{array}{c}\text { totally } \\
\text { within } 3 \\
\text { hours }\end{array}$ & $\begin{array}{l}\text { length of routes } \\
\text { within ground } \\
\text { protection zone }\end{array}$ & more than 3 hours \\
\hline 2002 & . & 6436.7 & 12565.5 & 9337.7 & 28339.9 & 6231.0 & 13297.1 \\
\hline 2003 & 253827.0 & 17691.0 & 53613.4 & 46686.4 & 117990.8 & 17720.7 & 135836.1 \\
\hline 2004 & 15318.3 & 1907.2 & 4411.6 & 3403.7 & 9722.4 & 781.2 & 5595.8 \\
\hline 2005 & 39401.5 & 5503.5 & 10238.7 & 5974.4 & 21716.6 & 6026.0 & 17684.9 \\
\hline 2006 & 54516.0 & 8267.6 & 16165.1 & 6647.0 & 31079.6 & 6503.8 & 23436.4 \\
\hline 2007 & 58087.5 & 7521.8 & 13183.2 & 9194.0 & 29899.0 & 3554.7 & 28188.6 \\
\hline 2008 & 78193.5 & 13647.9 & 28922.4 & 10349.7 & 52920.0 & 10278.8 & 25273.4 \\
\hline 2009 & 42646.8 & 4643.9 & 9219.3 & 5941.2 & 19804.4 & 4259.6 & 22842.4 \\
\hline 2010 & 41433.0 & 5515.1 & 12290.6 & 6157.1 & 23962.8 & 4860.9 & 17470.2 \\
\hline 2011 & 96952.4 & 10210.4 & 24772.1 & 14872.1 & 49854.6 & 6757.4 & 47097.8 \\
\hline 2012 & 61029.2 & 5792.9 & 12753.5 & 9141.8 & 27688.3 & 4066.6 & 33341.0 \\
\hline 2013 & 62175.7 & 7865.1 & 15817.6 & 7597.6 & 31280.2 & 7082.1 & 30895.5 \\
\hline 2014 & 137239.0 & 12952.1 & 30069.3 & 19446.2 & 62467.5 & 8589.0 & 74771.4 \\
\hline 2015 & 63897.8 & 4915.6 & 13299.3 & 9749.9 & 27964.8 & 4139.9 & 35933.0 \\
\hline 2016 & 104374.7 & 3739.5 & 8581.4 & 9709.1 & 22030.0 & 2534.9 & 82344.8 \\
\hline 2017 & 67478.9 & 4962.0 & 9842.9 & 9452.2 & 24257.2 & 2814.5 & 43221.8 \\
\hline Total & 1218208.1 & 121572.3 & 275745.9 & 183660.1 & 580978.0 & 96201.0 & 637230.1 \\
\hline Average value & 76138.0 & 7598.3 & 17234.1 & 11478.8 & 36311.1 & 6012.6 & 39826.9 \\
\hline $\begin{array}{l}\text { Standard } \\
\text { deviation }\end{array}$ & 55706.3 & 4147.0 & 12083.3 & 10113.5 & 25574.1 & 3927.1 & 32881.7 \\
\hline
\end{tabular}




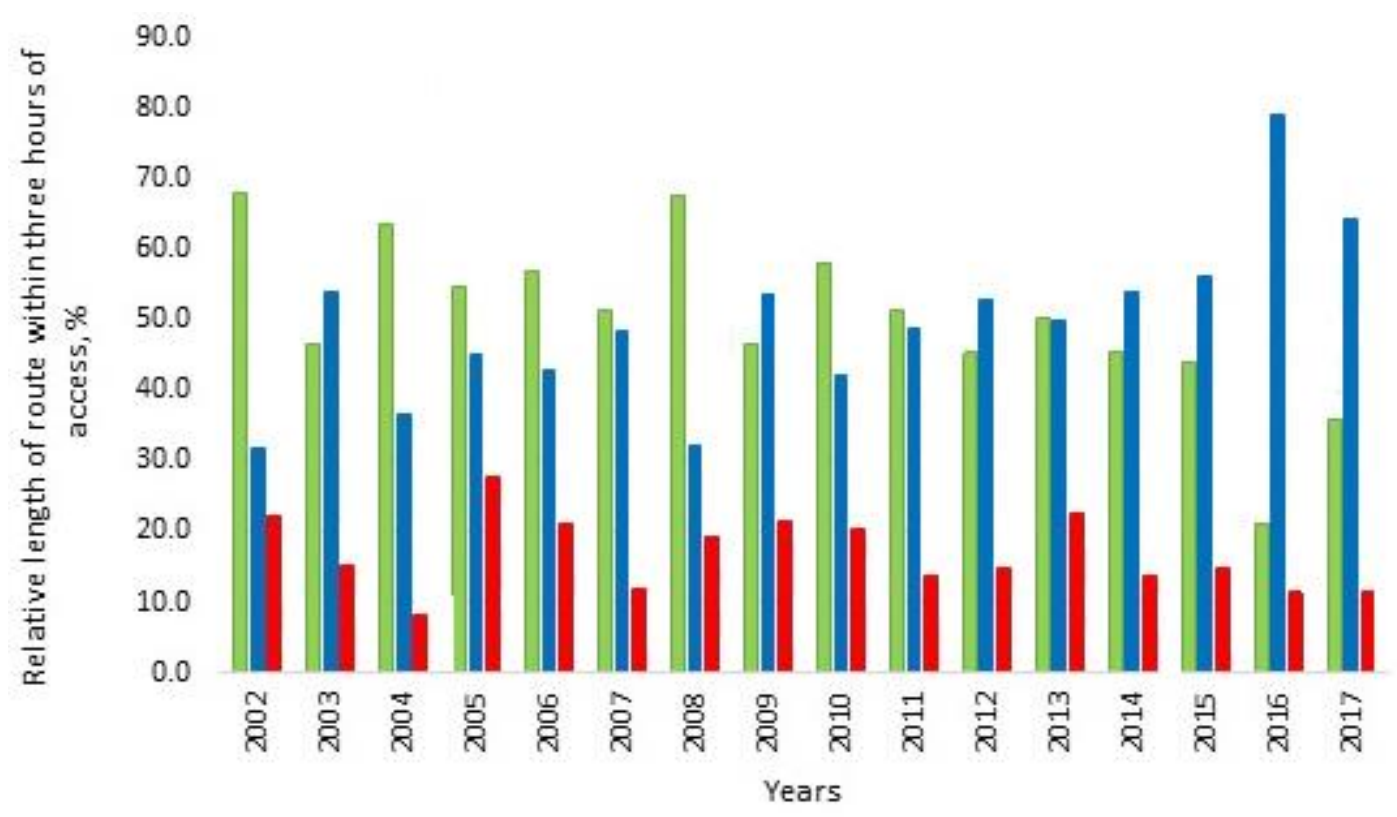

Fig. 9. Distribution of relative length of routes (\%) to the forest fires within the ground and aviation protection zones, travelling time is three hours (green color), more than three hours (blue color), and total length of routes within ground zone (red color)

According to these statistics, the ground protection zone can also be extended to three hours (Fig. 9), if it is economically profitable with the respect to aviation transport modes and methods of extinguishing forest fires.

\section{CONCLUSIONS}

In the paper we have shown a possibility to use the forest fire transportation model to make the quantitative estimations of travelled time and length for the access routes made from the fire stations to the forest fires within the ground and aviation protection zones. Based on the results obtained, the following conclusions can be drawn.

1. Created transport model allowed building routes for $98 \%$ of forest fires registered in the ground protection zone under the condition that the transfer of human forces and technical means for them is not more than three hours. This indirectly confirms the correctness of the selected parameters for the model. It is planned to compare the simulation results (as they are shown in this paper) to the real tracks of the fire trucks for the next fire hazard seasons. This will also allow to do a spatial analysis of coincidence between routes in the real conditions and the model calculations.

2. It is necessary to update the regional attribute and spatial data on the roads and forest glades in order to add the practical value to the created transport model. Transport 
model can be used to choose a method of forces and equipment delivery (ground / aviation) to the forest fires, as well as their maneuvering in conditions of high and extreme forest burning with limited regional resources. It will also expand the opportunities for interaction between the different regional departments and the tenants of the forest fund lands involved into the forest fires extinguishing.

3. The transport model created can become a basis for solving more complex management tasks, namely, estimating the time spent on the forces and equipment transfer between a forest fire site and a fire station, taking into consideration transport movement parameters in the cities, maneuvering with the firefighting forces involvement between the regions and forest fire units of federal subordination.

4. Established long-term access routes database allows to evaluate and to adjust the boundaries between ground and forest aviation protection zones, taking into account temporary accessibility of the forest fund territory by public and special roads (fire roads, forest glades, etc.).

\section{ACKNOWLEDGEMENTS}

The work has been supported by the state funding contract "Development of methodological approaches to the remote monitoring of resource potential and ecological state of forest ecosystems" (topic N AAAA-A18-118052400130-7).

\section{REFERENCES}

Abousaeidi M., Fauzi R., Muhamad R. Geographic Information System (GIS) modeling approach to determine the fastest delivery routes, Saudi Journal of Biological Sciences, 2016, vol. 23, pp. 555-564, DOI:10.1016/j.sjbs.2015.06.004.

Abousaeidi M., Fauzi R., Muhamad R. Determining efficient delivery routes in specific time-frames using Geographic Information System, Journal of Environmental Biology, Vol. 37 (Special Issue), September 2016, pp. 1167-1176.

Akay A., Aziz B. GIS-Based forest road network model for forest protection purposes, 38th Annual COFE Meeting. Engineering solutions for non-industrial private forest operations, 2015, pp. 266-281.

Akay A.E., Wing M.G., Sivrikaya F., Sakar D.A. GIS-based decision support system for determining the shortest and safest route to forest fires: a case study in Mediterranean 
Region of Turkey, Environment Monitoring Assess, 2012, No. 184, pp. 1391-1407, doi:10.1007/s10661-011-2049-z.

Akay A., Kakol A. Forest transportation planning by using GIS-based decision support system, 2014, http://fec2014.fcba.fr/wp-content/uploads/sites/4/2014/11/a93.pdf.

Alazab A., Venkatraman S., Abawajy J., Alazab, M. An optimal transportation routing approach using GIS-based dynamic traffic flows, 3rd International Conference on Information and Financial Engineering IPEDR, 2011, Vol. 12, IACSIT Press, pp. 172-178.

Bryukhanov A.V., «Lesopozharnyj likbez»: 12 oshibochnyh mnenij o prirodnyh pozharah, Ustojchivoe lesopol'zovanie ('Forest firefighting education program': 12 mistaken opinions about the wild fires), Sustainable forest management, 2011, No 3 (28), pp. 11-21. https://aviales.ru/files/documents/2011/10/12mn.unpublished.pdf

Bryukhanov A.V., Korshunov N.A., Aviacionnoe tushenie prirodnyh pozharov: istorija, sovremennoe sostojanie, problemy i predposylki (Aerial wildfire fighting: history, current situation, problems and perspectives), Siberian Forest Journal, 2017. No 5. pp. 37-54.

Dijkstra E.W. A note on two problems in connexion with graphs, Numerische Mathematik, 1959, Vol. 1, pp. 269-271, doi:10.1007/BF01386390.

Faraonov A.V., Razrabotka situacionnoj modeli zadachi marshrutizacii pri neobhodimosti izmenenija opornogo plana na osnove nechetkoj situacionnoj seti (Development of situation model of transportation task based on fuzzy situational network), XII All-Russia meeting on the management problems, Moscow, June 2014, pp. 5101-5113.

Feng G., Sun Zh., Su G. Optimal route of emergency resource scheduling based on GIS. 3rd ACM SIGSPATIAL Workshop, November 2017. DOI>10.1145/3152465.3152471.

Forkuo E.K., Quaye-Ballard J.A. GIS-based fire emergency response system, International Journal of Remote Sensing and GIS, 2013, Vol. 2, Issue 1, pp. 32-40.

Goldammer J.G., Sukhinin A., Csiszar I. Current fire situation in the Russian Federation: Implications for enhancing international and regional cooperation in the UN Framework and the global programs on fire monitoring and assessment, GFMC contribution to the International Workshop "New Approaches to Forest Protection and Fire Management at an Ecosystem Level”, Khabarovsk, Russian Federation, 2003, pp. 1-24.

How to create the shortest route, URL: http://faqs.org.ru/progr/graph/pathmake.htm.

Idhoko K.E, Aguba W., Emefeke U., Nwanguma C. Development of a geographic information systems road network database for emergency response: A case study of Oyo- 
Town, Oyo State, Nigeria, International Journal of Engineering Science Invention ISSN, 2015, Vol. 4 (12), pp. 34-42.

Jawad F.F., Shabana B.T., El-Bakry H.M. Reducing waiting time for transportation using GIS, International Journal of Advanced Research in Computer Science \& Technology, (IJARCST), 2016, Vol. 62, No 4 (1). pp. 62-71.

Kaibicheva E.I., Kaibichev I.A., Indeks chisla lesnyh pozharov v Rossijskoj Federacii za 2006-2010 gg. (Forest fires number index in Russian Federation in 2006-2010), Fire and explosion safety, 2013, Vol. 22, No 5. pp. 45-50.

Keramati A. Solving the log-truck routing problem while accounting for forest road maintenance levels: a case study of Oregon, Transportation Research Board 97th Annual Meeting, 2018, 6 p., https://trid.trb.org/view/1495908.

Khodakov V.E., Zharikova M.V., Lesnye pozhary: metody issledovanija (Forest fires: research methods), Kherson: Grin D.S., 2011. 470 p.

Kotelnikov R.V., Korshunov N.A., Giryaev N.M., Zadachi prinjatija reshenij v oblasti ohrany lesov ot pozharov: osnovnye prioritety razvitija informacionnogo obespechenija (Objectives of decision making in protecting forests from fires. Priorities on development of informational support), Siberian Forest Journal, 2017, No 5, pp. 18-24, doi: 10.15372/SJFS20170502.

Kumar P., Singh V., Reddy D. Advanced traveler information system for Hyderabad City. IEEE Transactions on intelligent transportation systems, 2005, Vol. 6 (1), pp. 26-37, DOI: 10.1109/TITS.2004.838179.

Legend for the forest fire prevention. Appendix 14., 1997, http://docs.cntd.ru/document/58817250, (2019, 12 May).

Liu S., Zhu X. Accessibility analyst: an integrated GIS tool for accessibility analysis in urban transportation planning, Environment and Planning, Planning and Design, 2004, Vol. 31, pp. 105-124, https://DOI.org/10.1068/b305, (2019, 12 May).

Loupian E.A., Mazurov A.A., Flitman E.V., Ershov D.V., Korovin G.N., Novik V.P., Abushenko N.A., Altyntsev D.A., Koshelev V.V., Tashchilin S.A., Tatarnikov A.V., Csiszar I., Sukhinin A.I., Ponomarev E.I., Afonin S.V., Belov, V.V., Matvienko G.G., Loboda T., Satellite monitoring of forest fires in Russia at federal and regional levels, Mitigation and Adaptation Strategies for Global Change, 2006, Vol. 11, No 1, pp. 113-145. 
Malladi T., Sowlati T. Optimization of operational level transportation planning in forestry: a review, International Journal of Forest Engineering, 2017, Vol. 28, Issue 3, https://doi.org/10.1080/14942119.2017.1362825.

Ni K., Zhang, Y.-T., Ma Y.-P. Shortest path analysis based on Dijkstra's algorithm in emergency response system, Telkomnika Indonesian Journal of Electrical Engineering, 2014, Vol. 12 (5), pp. 3476-3482, doi: http://dx.doi.org/10.11591/telkomnika.v12i5.3236.

NOAA Global ETopo2. URL: https://www.ngdc.noaa.gov/mgg/global/etopo2.html

Oleynikov V.T., Markov A.G., Problemy razrabotki i ispol'zovanija geoinformacionnyh sistem v podrazdelenijah MChS Rossii (Problems of development and use of geoinformation systems in divisions of Emercom of Russia), Fire and explosion safety, 2014, N 8, pp. 32-35.

On approval of the classification of natural forest fire danger and the classification of forest fire danger depending on the weather conditions/ Order No 287, Federal Forestry Agency (Rosleshoz), 2011, https://rg.ru/2011/08/24/pojari-dok.html, (2019, 12 May).

Order of Federal Forestry Agency (Rosleshoz) No 65 dated 16.02.2017, http://docs.cntd.ru/document/456071028, (2019, 15 May).

Order of Ministry of Forest, Irkutsk region No 52 dated 21.06.2017, http://docs.cntd.ru/document/450255889, (2019, 12 May).

PDD, URL: http://pddgarazh.ru/pravila/skorost-dvizheniya.html (2019, 22 May).

Podolskaia E.S., Kovganko K.A., Ershov D.V., Plotnikova A.S., Sozdanie geoinformacionnoj modeli planirovanija optimal'nogo marshruta peremeshhenija nazemnyh sil i sredstv k mestu tushenija lesnyh pozharov (Creation of geoinformation model to plan an optimal route for ground access to the forest fires), Proceedings of II International scientific and technical conference "Forests of Russia: politics, industry, science and education". SaintPetersburg State Forest Technical University, 2017, pp. 200-202.

Ponomarev E.I., Kharuk V.I., Yakimov N.D., Rezul'taty i perspektivy sputnikovogo monitoringa prirodnyh pozharov Sibiri (Current results and perspectives of wildfire satellite monitoring in Siberia), Siberian Forest Journal, 2017, No 5. pp. 25-36.

Recommendations on the use of forces and technical means to extinguishing forest fores (Emercom of Russia, dated 16.07.2014 No 2-4-87-9-18), http://legalacts.ru/doc/metodicheskie-rekomendatsii-po-primeneniiu-sil-i-sredstv-dljatushenija/, (2019, 10 May). 
Runova E.M., Dolenko M.A., Lesnye pozhary v Irkutskoj oblasti (Forest fires in Irkutsk region), Proceedings of the Bratsk State University. Series: Natural and Engineering Sciences, 2006, Vol. 1. pp. 90-92.

Runova E.M., Kostyaev V.N., Podhod k proektirovaniju optimal'noj lesotransportnoj seti s pomoshh'ju matematicheskogo modelirovanija (An approach to design an optimal forest transport network with mathematical modelling), Systems. Methods. Technology, 2012, No 4 (16), pp. 170-176.

Sokolov A.P., Gerasimov Yu.Yu., Geoinformacionnaja sistema dlja reshenija optimizacionnoj zadachi transportnoj logistiki kruglyh lesomaterialov (Geoinformation system for solving optimization problem of transport logistics for round timber), IVUZ Forest Journal, 2009, No 3. pp. 78-85.

Tarantsev A.A. O probleme razmeshhenija vnov' sozdavaemyh pozharnyh chastej na territorijah regionov (On the problem of placing newly created fire brigades in the territories of the regions), Fire and explosion safety, 2013, Vol. 22, No 5, pp. 52-57.

Tarantsev A.A. Metodika opredelenija mest dislokacii pojetapno sozdavaemyh pozharnyh chastej v sel'skoj mestnosti i korrektirovki granic rajonov vyezda (Technique of dislocation of places for the fire departments gradually created in rural areas and corrections of boundaries of their departure's areas), Fire and explosion safety, 2015, No 4, pp. 72-78.

Territorial department of Federal State Statistics Service for Irkutsk region, URL: http://irkutskstat.gks.ru/wps/wcm/connect/rosstat_ts/irkutskstat/ru/statistics/enterprises/transp ort/, (2019, 12 May).

Reviewer: PhD in engineering Kushnyr' O.V. 